\author{
ANITA KULAWIAK \\ Uniwersytet Łódzki, Polska - University of Lodz, Poland \\ Karolina SmętKIEWICZ \\ Uniwersytet Pedagogiczny w Krakowie, Polska - Pedagogical University of Cracow, Poland
}

\title{
Przedsiębiorczość w opinii mieszkańców małego miasta. Przykład Konstantynowa Łódzkiego
}

\section{Entrepreneurship in the Opinion of the Inhabitants of a Small Town. The Example of Konstantynów Łódzki (Poland)}

\begin{abstract}
Streszczenie: Zagadnienie przedsiębiorczości, niezależnie od różnorakich sposób definiowania, zajmuje ważne miejsce w rozwoju społeczno-gospodarczym jednostek terytorialnych. W literaturze przedmiotu poruszane są nie tylko kwestie sposobów rozumienia tego pojęcia czy też uwarunkowań rozwoju przedsiębiorczości, lecz również kwestie postrzegania przedsiębiorczości przez społeczeństwo. Wizerunek przedsiębiorców i przedsiębiorczości w oczach społeczeństwa jest istotnym czynnikiem lokalnym, odgrywającym ważną rolę w pobudzaniu zachowań przedsiębiorczych i w konsekwencji - w rozwoju społeczno-gospodarczym lokalnych i regionalnych układów przestrzennych. Celem głównym niniejszego artykułu jest poznanie i przedstawienie opinii mieszkańców małego miasta (na przykładzie Konstantynowa Łódzkiego) na temat przedsiębiorców i przedsiębiorczości. Założenia badawcze, które zostały poddane weryfikacji w toku badań, dotyczą czynników społecznych sprzyjających rozwojowi przedsiębiorczości (pozytywna opinia mieszkańców miasta o przedsiębiorcach i akceptacja społeczna dla ich działalności), a także potencjalnych barier w rozwoju przedsiębiorczości. W celu sprawdzenia założeń badawczych przeprowadzono badania bezpośrednie z wykorzystaniem kwestionariusza wywiadu, który przeprowadzono w grupie 470 mieszkańców Konstantynowa Łódzkiego. Uzyskane wyniki potwierdzają zaobserwowany w Polsce trend, że wizerunek przedsiębiorcy i przedsiębiorczości w ostatnim czasie uległ znacznemu ociepleniu. Zdecydowana większość respondentów bardzo pozytywnie odbiera przedsiębiorców, przypisując im jednocześnie ważną i potrzebną w rolę gospodarce. Podobnie pozytywne skojarzenia budzi termin „przedsiębiorczość”, chociaż większość respondentów nie myśli o założeniu własnej firmy. Pozytywne jest jednak to, że przyczyną tego stanu są warunki makroekonomiczne, w których funkcjonuje państwo, a nie lokalne, które stwarza ich miasto. Te ostatnie oceniane są w większości wysoko, co świadczy o sprzyjającej atmosferze do rozwoju przedsiębiorczości w Konstantynowie Łódzkim.
\end{abstract}

\footnotetext{
Abstract: The issue of entrepreneurship, regardless of the various ways of defining it, occupies an important place in the socio-economic development of territorial units. The literature on the subject concerns not only the ways of understanding this concept, or the conditions for the development of entrepreneurship, but also the issues of public perception of entrepreneurship. The image of entrepreneurs and entrepreneurship in the eyes of the public is an important local factor, playing an important role in stim-
} 
ulating entrepreneurial behaviours and, as a consequence, socio-economic development of local and regional spatial systems. The main objective of this article is to get to know and present the opinions of the inhabitants of a small town (based on the example of Konstantynów Łódzki) about entrepreneurs and entrepreneurship. Research assumptions that have been verified in the course of research concern social factors conducive to the development of entrepreneurship (positive opinion of residents about entrepreneurs and social acceptance for their activities), as well as potential barriers in the development of entrepreneurship. For this purpose, direct research was conducted using an interview questionnaire, which was carried out on a group of 470 residents of Konstantynów Łódzki. The obtained results confirm the trend observed in Poland that the image of the entrepreneur and entrepreneurship has been significantly warmed up recently. The vast majority of respondents perceive entrepreneurs very positively, at the same time assigning them an important and needed role in the economy. Similarly positive associations are also raised by the term entrepreneurship. And although most respondents do not think about starting their own company, the positive is that the reason for this state are the macroeconomic conditions in which the state functions, not the local ones that the town creates. The latter are rated mostly high and it confirms a beneficial atmosphere for the development of entrepreneurship in Konstantynów Łódzki.

Słowa kluczowe: Konstantynów Łódzki; opinie mieszkańców; percepcja środowiska; postrzeganie przedsiębiorców; przedsiębiorca; przedsiębiorczość; wizerunek przedsiębiorcy

Key words: entrepreneur; entrepreneurship; image of the entrepreneur; Konstantynów Łódzki; opinions of residents; perception of the environment

Otrzymano: 19 listopada 2018

Received: 19 November 2018

Zaakceptowano: 4 marca 2019

Accepted: 4 March 2019

\section{Sugerowana cytacja/Suggested citation:}

Kulawiak, A., Smętkiewicz, K. (2019). Przedsiębiorczość w opinii mieszkańców małego miasta. Przykład Konstantynowa Łódzkiego. Przedsiębiorczość - Edukacja [Entrepreneurship - Education], 15(1), 191-204. doi: 10.24917/20833296.151.14

\section{Wstęp: zakres przedmiotowy badań}

Zagadnienie przedsiębiorczości jest współcześnie bardzo ważnym elementem rozważań w naukach społecznych, w tym szczególnie na gruncie ekonomii, socjologii i psychologii. Wynika to przede wszystkim z jego znacznej złożoności teoretycznej, jak i doniosłości praktycznej. Nikt obecnie nie kwestionuje tego, że przedsiębiorczość, niezależnie od sposobu jej definiowania, spełnia szereg bardzo ważnych funkcji, w tym istotnie przyczynia się do rozwoju społeczno-gospodarczego. Stąd też w literaturze przedmiotu dużo miejsca poświęca się czynnikom warunkującym jej rozwój, wyróżniając wśród nich zarówno cechy osobowościowe przedsiębiorców, jak i uwarunkowania makroekonomiczne i lokalne. Współcześnie podejmuje się także tematykę postrzegania (wizerunku) przedsiębiorczości przez społeczeństwo, uznając go za istotny czynnik lokalny, odgrywający ważną rolę w pobudzaniu zachowań przedsiębiorczych. Założenie to wynika $\mathrm{z}$ faktu, że postrzeganie, jako proces dynamiczny, oznaczający całość ludzkiego doświadczenia świata: wiedzę, klasyfikacje, teorie, mity, związki między zjawiskami poprzedza, jak dowodzą psychologowie, zewnętrzne zachowanie się człowieka, a zatem wpływa na jego stosunek do samego siebie i innych, sposób funkcjonowania w środowisku, umiejętność komunikowania się $\mathrm{z}$ otoczeniem oraz charakter przyjmowanych przez niego ról społecznych. Zachowanie 
ludzkie wykazuje zatem silny związek z percepcją otaczającego środowiska. Można także założyć, że decyduje ono o wejściu człowieka lub nie w rolę przedsiębiorcy. Pochodną postrzegania środowiska przez człowieka jest bowiem wykształcenie względem niego postawy sympatii lub antypatii. Dobry wizerunek sprawia, że dana osoba jest lubiana, jej działalność spotyka się z aprobatą, a postawa i głoszone przez nią poglądy nie tylko zyskują uznanie, ale mogą również uchodzić za wzór do naśladowania. I odwrotnie. Postrzeganie ma zatem znaczenie nie tylko dla zysku samych zainteresowanych, ale także dla całego społeczeństwa i gospodarki (Braziewicz-Kumor, 2016). Zwraca na to uwagę m.in. P. Sztompka, pisząc: „sposób, w jaki poszczególne jednostki waloryzują otaczającą rzeczywistość, wpływa na ich działania, a w efekcie na współtworzone przez te jednostki procesy społeczne. Zmiany mentalności wpływają więc na przebieg procesu zmian dokonujących się w obrębie społeczeństwa” (Cierniak-Szóstak, 2006: 197).

Uznając postrzeganie przedsiębiorczości za ważne i interesujące zagadnienie badawcze, $\mathrm{w}$ artykule podjęto problem identyfikacji opinii mieszkańców małego miasta o przedsiębiorcach i przedsiębiorczości. Celem głównym artykułu jest zatem poznanie i przedstawienie opinii mieszkańców małego miasta (na przykładzie Konstantynowa Łódzkiego) na temat przedsiębiorców i przedsiębiorczości. Celami szczegółowymi pracy są:

- przedstawienie przeglądu literatury przedmiotu związanej z wizerunkiem przedsiębiorcy,

- przedstawienie czynników warunkujacych postrzeganie osób przedsiębiorczych,

- poznanie sposobu rozumienia pojęcia przedsiębiorczości i przedsiębiorcy przez mieszkańców małego miasta, a także poznanie cech charakteryzujących przedsiębiorców, wymienianych przez mieszkańców Konstantynowa Łódzkiego,

- identyfikacja znaczenia, jakie w opinii społeczności lokalnej Konstantynowa Łódzkiego ma przedsiębiorczość we współczesnym funkcjonowaniu społeczno-gospodarczym miasta,

- poznanie czynników utrudniających (barier) i sprzyjających w procesie rozwoju przedsiębiorczości, na przykładzie Konstantynowa Łódzkiego.

W artykule sformułowano następujące założenia badawcze, które zostały poddane weryfikacji za pomocą metod badawczych:

- Nastawienie społeczeństwa polskiego do przedsiębiorców na przestrzeni ostatnich lat ulega stopniowej poprawie i jest to widoczne w przypadku Konstantynowa Łódzkiego, w którym opinie mieszkańców wskazują na sytuację sprzyjającą rozwojowi przedsiębiorczości i akceptację społeczną dla tego typu działalności.

- Wizerunek przedsiębiorców w Konstantynowie Łódzkim w opinii mieszkańców miasta jest pozytywny i reprezentowany jest przez cechy osobowościowe wysoce pożądane na obecnym rynku pracy.

- Pomimo sytuacji sprzyjającej rozwojowi przedsiębiorczości w Konstantynowie Łódzkim, związanej z postrzeganiem społecznym, istnieją jednak inne bariery ekonomiczne w tworzeniu i funkcjonowaniu prywatnych firm.

Podjęta problematyka badawcza sytuuje pracę w obrębie geografii behawioralnej, a ściślej - w nurcie określanym geografią percepcji. Chociaż wprawdzie prowadzone dotychczas w Polsce badania percepcji dotyczyły postrzegania przestrzeni, a nie jednostek ludzkich, w tym skupiały się głównie na badaniu świadomości terytorialnej mieszkańców, wyobrażeń i preferencji przestrzennych (Bartnicka, 1986; Budner, Matykowski, 1992; Gwosdz, 2001; Jałowiecki, 1996; Kaczmarek, Szafrańska, 2007; Libura, 1988, 1990; 
Mordwa, 1993, 2003; Szkurłat, 2004, 2006; Rembowska, 2000; Rykiel, 1985; Tobiasz-Lis, 2013), a także dotyczyły świadomości społecznej różnych działań gospodarczych, np. wykorzystania wód geotermalnych (Smętkiewicz, 2014), to jednak aktualny zakres i kierunek podejmowanych w ramach tego nurtu badań stwarza szansę i możliwości jego rozszerzenia o nowe elementy. Tym bardziej, że w ramach geografii społecznej prowadzi się już badania nad społecznymi uwarunkowaniami rozwoju przedsiębiorczości (Kulawiak, Suliborski, 2006; Kulawiak, 2011; Kulawiak, 2013).

Do przeanalizowania założonego problemu wykorzystano głównie technikę wywiadu kwestionariuszowego w ramach metod jakościowych. Wywiad ten przeprowadzono w okresie od maja do czerwca 2017 r. Ankieta badawcza była skierowana do mieszkańców Konstantynowa Łódzkiego, którzy w dniu badania mieli ukończone 18 lat. W sumie zebrano 470 poprawnie wypełnionych kwestionariuszy, co stanowiło $94 \%$ założonych na początku badania. Większość ankietowanych stanowiły kobiety (62\%). Ponadto, w badaniach dominowały osoby w średnim wieku, to jest między 35 a 54 rokiem życia (71\%), deklarujące wykształcenie średnie (47\%) i wyższe (32\%). Pod względem zatrudnienia nieznacznie przeważały osoby pracujące w firmach prywatnych (45\%) nad osobami zatrudnionymi w sferze publicznej (36\%).

Artykuł składa się z części teoretycznej, obejmującej przegląd literatury przedmiotu związanej z wizerunkiem przedsiębiorcy oraz przedstawienie uwarunkowań postrzegania osób przedsiębiorczych w świetle literatury, oraz części empirycznej, w ramach której scharakteryzowano obszar badań, a następnie przedstawiono wyniki pracy empirycznej, tj. zaprezentowano zagadnienie postrzegania przedsiębiorców i przedsiębiorczości przez mieszkańców Konstantynowa Łódzkiego. Artykuł zakończono wnioskami stanowiącymi podsumowanie przeglądu literatury oraz najważniejszych wyników badań.

\section{Wizerunek przedsiębiorcy w literaturze przedmiotu}

Koncepcja społecznej legitymizacji przedsiębiorczości jest jednym z podejść mieszczących się w ramach kulturowego paradygmatu przedsiębiorczości, gdyż w tworzeniu reputacji przedsiębiorstw i przedsiębiorców najważniejszą rolę odgrywają przede wszystkim parametry pozaekonomiczne, takie jak: system wartości i norm, tradycje przedsiębiorczości w danym społeczeństwie, model rodziny, kompetencje i wiedza społeczeństwa oraz kapitał zaufania społecznego. Pierwsze opracowania dotyczące tej problematyki powstały już w pierwszej połowie XX w. w Stanach Zjednoczonych oraz w krajach Europy Zachodniej, tj. we Francji i Anglii (Cochran, 1949; Landes, 1951; Sawyer, 1952). W Polsce badania nad przedsiębiorczością, a szerzej - klasą średnią i jej wizerunkiem w oczach własnych i społeczeństwa - pojawiły się natomiast dość późno, to jest w latach 80. XX w. Przyczyn tego stanu było wiele, ale za najważniejsze należy uznać względną słabość tej grupy społecznej oraz fakt, że przez cały okres międzywojenny i czasy PRL-u działalność gospodarcza w Polsce nie cieszyła się prestiżem ani popularnością, ustępując miejsca działalności dobroczynnej czy kulturalnej. Jak pisze Cierniak-Szóstak „W okresie międzywojennym znaczenie tej grupy społecznej było marginalizowane przez istnienie obok niej drugiej elity społecznej w postaci dystansujących ją prestiżem ziemiaństwa i arystokracji, natomiast w okresie realnego socjalizmu o społecznym uznaniu decydowała praca na państwowej posadzie, a nie bogacenie się traktowane jako chciwość" (Cierniak-Szóstak, 2008: 400). Stąd też w polskiej literaturze przedmiotu nie tylko rzadko podejmowano problematykę 
przedsiębiorcy i przedsiębiorczości, ale także, jeżeli już, opisywano ją w kategoriach negatywnych, używając określeń pejoratywnych (nieuczciwy, żyjący kosztem innych, wyzyskiwacz, prywaciarz). Rozwój opracowań poświęconych tej tematyce można zaobserwować dopiero wraz z nastaniem w Polsce liberalizacji społeczno-gospodarczej i rozwojem prywatnych podmiotów gospodarczych. Dostrzeżenie jej ogromnego znaczenia dla gospodarki i społeczeństw spowodowało także wzrost badań nad czynnikami determinującymi jej rozwój. W konsekwencji zauważono, że obok czynników ekonomicznych ważne są także uwarunkowania kulturowe, a wśród nich i wizerunek przedsiębiorcy. Temat ten chętnie podejmowany jest głównie przez socjologów i ekonomistów (Cierniak-Szóstak, 2008; Glinka, 2008; Hryniewicz, 1996; Jasicki, 2004; Kola-Bezka, 2012; Majewska, 2003; Rogulska, 2004; Tkaczyk, Rachwalska, 1997). W geografii natomiast nie znalazł on jeszcze swojego miejsca. Aktualnie na gruncie tej dyscypliny przedsiębiorczość utożsamiana jest głównie $\mathrm{z}$ indywidualnymi, prywatnymi podmiotami gospodarczymi i analizowana jest z punktu widzenia jej lokalizacji w przestrzeni (Domański, 1997; Śleszyński, 2002, 2003; Szymańska, Płaziak, 2010; Kamińska, 1997; Stryjakiewicz, 2009; Wieloński, 2004; Fierla, Kuciński, 2001), poziomu rozwoju w układzie lokalnym i/lub regionalnym (Kulawiak, 2012; Kamińska, 2006; Pałka, 2010; Kołodziejczyk, 1999; 2004), oraz czynników jej rozwoju, w tym także czynników społecznych (Suliborski, Kulawiak, 2006; Kulawiak, 2011; Kulawiak, 2013). Z uwagi jednak na fakt, że geografia ma silnie rozwinięte tradycje badań w zakresie percepcji środowiska (Libura, 1990; Madurowicz 2007; Rembowska, 2000; Szkurłat 2007; Tobiasz-Lis, 2013; Gwosdz, 2001) niniejszy artykuł jest próbą włączenia się geografów w ten nowy nurt badań na podstawie dorobku geografii humanistycznej i geografii percepcji.

\section{Uwarunkowania postrzegania osób przedsiębiorczych}

W poznawaniu otoczenia, w tym również drugiego człowieka, ludzie wykorzystują percepcję, którą często, szczególnie w psychologii, utożsamia się z postrzeganiem. Postrzeganie lub percepcja to, w terminologii psychologicznej, proces bezpośredniego odzwierciedlenia zjawisk w ich różnych wartościach zachodzących dzięki współdziałaniu analizatorów na podstawie już istniejącego doświadczenia danej osoby (Pecyna, 1997). Potocznie zaś, na gruncie tej nauki, za postrzeganie przyjmuje się proces „wchłaniania danych zmysłowych" przez jednostkę w takiej postaci, w jakiej realnie one istnieją. W geografii z kolei, która z założenia bada relacje zachodzące między człowiekiem a środowiskiem, percepcję traktuje się jako pewien proces społeczny, pośredniczący w tej relacji, i definiuje się ją jako „proces poznawczego strukturalizowania bodźców społecznych (pochodzących z szeroko rozumianego środowiska), na które wpływ wywierają genetyczna struktura i cechy kulturowe jednostki”. Jest to zatem pojęcie dynamiczne, oznaczające całość ludzkiego doświadczenia świata: wiedzę, klasyfikacje, teorie, mity, związki między zjawiskami (Bartnicka, 1989). Należy dodać, że percepcja, niezależnie od sposobu jej definiowania, odpowiada za powstanie w świadomości jednostki subiektywnego obrazu rzeczywistości, będącego efektem doświadczeń jednostki, jej nastawienia i obecnego stanu emocjonalnego. Spostrzeganie jest bowiem aktywne i twórcze, gdyż człowiek nie tylko rejestruje docierające do niego informacje, ale także aktywnie je przetwarza, selekcjonuje i interpretuje zgodnie ze zgromadzonymi w pamięci danymi o otoczeniu (Wolińska, 2015). Percepcję determinuje zatem wiele różnorodnych czynników, które w psychologii określa 
się wspólną nazwą tzw. schematów poznawczych. W najbardziej ogólnym znaczeniu na pojęcie to składa się wszystko to, co zgromadzone zostało przez lata zarówno w naszej pamięci semantycznej (wiedza o świecie, pamięć znaczeń), jak i epizodycznej (wspomnienia). W innym ujęciu do czynników wpływających na percepcję zalicza się także:

- oczekiwania, których źródłami są kultura, osobowość, płeć, status społeczny,

- język, jakiego jednostka używa oraz związany z nim sposob klasyfikacji ludzi, rzeczy,

- okoliczności, w jakich jednostka postrzega dany obiekt,

- wyznawane przez jednostkę postawy/wartości,

- sposób postrzegania (logicznie czy uczuciowo),

- emocje, które towarzyszą jednostce w chwili odbioru danego obiektu.

Zdaniem geografów behawioralnych na informację, którą człowiek uzyskuje od środowiska, wpływa z kolei status informacyjny środowiska, a także cechy psychiczne, fizyczne i kulturowe człowieka.

Postrzeganie przez człowieka jakiegoś obiektu (osoby, przedmiotu, zdarzenia, idei) zawsze zawiera w sobie komponent wartościujący i komponent emocjonalny. Z tego też względu postrzeganie, na gruncie psychologii, często utożsamiane jest z postawą. Postawa to bowiem nic innego jak trwały wzorzec wartościujący reakcji na daną osobę, obiekt lub sprawę. W myśl często przytaczanej klasycznej definicji jest to również mniej lub bardziej spójny wzorzec afektywnych, kognitywnych i konatywnych, czyli behawioralnych reakcji (uczuć, myśli, zachowań) w stosunku do obiektu psychologicznego lub też prościej - względnie trwała tendencja do pozytywnego lub negatywnego wartościowania danego obiektu przez człowieka. W świetle różnych teorii psychologicznych (m.in. teorii schematów poznawczych) współczesne rozumienie postawy zawiera zwykle kilka komponentów: a) komponent poznawczy, określający zasób informacji, wiedzę i przekonania wobec przedmiotu postawy, b) komponent afektywny, czyli uczucia przejawiane w stosunku do przedmiotu postawy, mające określony kierunek i siłę oraz c) komponent behawioralny, tzn. zachowania intencjonalne bądź zachowania realne wobec przedmiotu postawy (Bujnowska, 2009).

W artykule identyfikacji stosunku społeczności lokalnej do przedsiębiorców i przedsiębiorczości dokonano m.in. na podstawie dwóch pierwszych komponentów postawy: komponentu poznawczego i afektywnego.

\section{Charakterystyka obszaru badań}

Konstantynów Łódzki położony jest w centralnej części województwa łódzkiego, ok. 10 km na zachód od stolicy województwa Łodzi i wchodzi w skład Łódzkiego Zespołu Miejskiego (rycina 1). Znajduje się on w pobliżu tras szybkiego ruchu - drogi ekspresowej S14, autostrad A-1, A-8 - a także w pobliżu Portu Lotniczego im. Władysława Reymonta w Łodzi. Położenie komunikacyjne miasta stwarza zatem dobre warunki dla jego rozwoju społeczno-gospodarczego.

Powierzchnia Konstantynowa Łódzkiego wynosi 26,87 km², co stanowi 5,64\% ogólnej powierzchni powiatu oraz $0,2 \%$ powierzchni województwa. Miasto zamieszkuje ok. 17,9 tys. mieszkańców, a średnia gęstość zaludnienia wynosi 657 os. $/ \mathrm{km}^{2}$. Ludność miasta stanowi 0,6\% ogółu ludności województwa i 14,5\% ogółu ludności powiatu 
Rycina 1. Położenie Konstantynowa Łódzkiego na tle województwa łódzkiego i powiatu pabianickiego

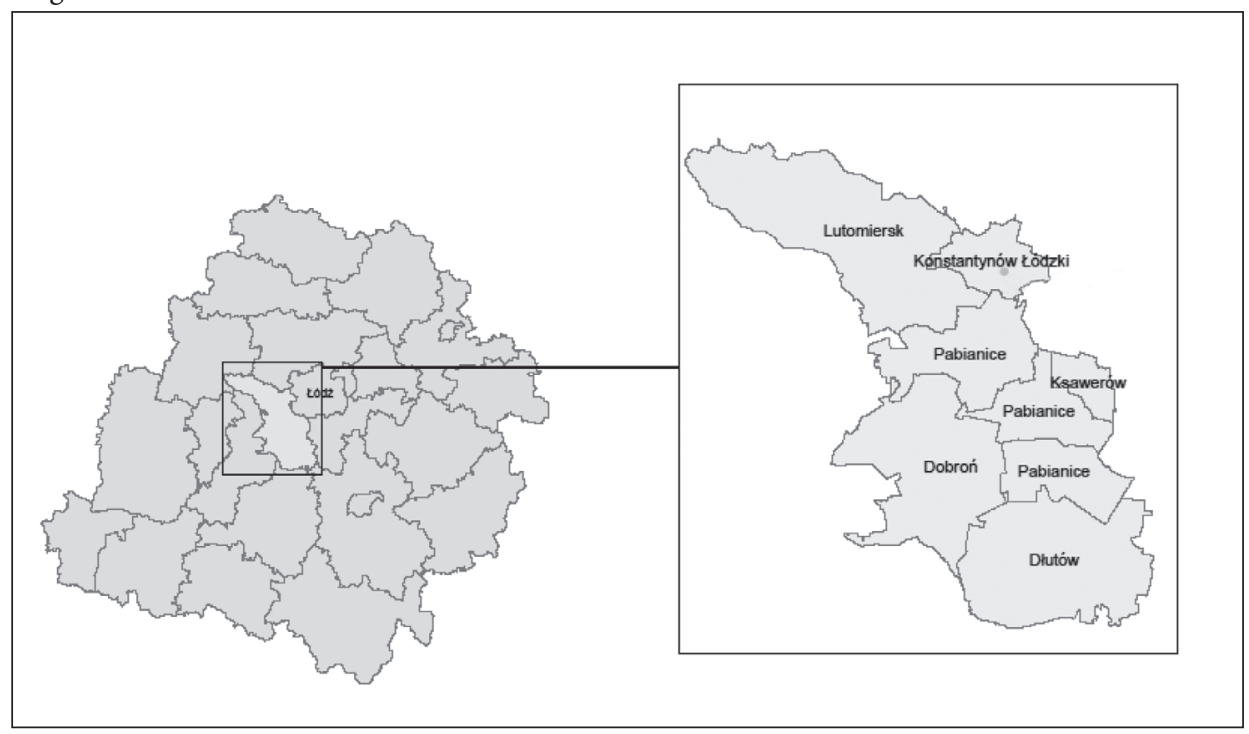

Źródło: opracowanie własne

pabianickiego ${ }^{1}$. W strukturze demograficznej mieszkańców Konstantynowa Łódzkiego przeważają kobiety, na które przypada 53\% ogólnej populacji miasta. Ta nieznaczna przewaga kobiet ma swoje uzasadnienie w charakterze funkcjonalnym miasta, które od początku swojego istnienia aż do lat 90 . było miastem typowo włókienniczym. W ciągu ostatnich 15 lat liczba ludności miasta nieznacznie wzrosła (o 2,1\%), co należy uznać za korzystną tendencję. Miasto to cechuje niestety niekorzystna struktura ekonomiczna wyróżniająca się nadmiernym udziałem osób w wieku poprodukcyjnym (23\%), w stosunku do osób w wieku przedprodukcyjnym (16\%). Aktualnie bez pracy pozostaje w mieście blisko $10 \%$ osób i są to głównie osoby młode i bardzo młode, to jest albo przed 25 rokiem życia, albo między 30 a 35 rokiem życia. Przedsiębiorczość mierzona natężeniem firm osób fizycznych przypadających na 1000 mieszkańców jest na średnim poziomie i wynosi 80 , co w porównaniu z innymi najmniejszymi miastami regionu łódzkiego wskazuje, że miasto posiada jeszcze pewien niewykorzystany w tym zakresie potencjał. W $2016 \mathrm{r}$. liczba zarejestrowanych podmiotów wyniosła tam blisko 1500, przy czym były to firmy głównie handlowe i usługowe (tabela 1).

Tabela 1. Liczba podmiotów osób fizycznych w najmniejszych miastach regionu łódzkiego w 2017 r.

\begin{tabular}{|l|c|c|c|}
\hline \multicolumn{1}{|c|}{ Miasto } & Liczba ludności & $\begin{array}{c}\text { Liczba podmiotów } \\
\text { osób fizycznych }\end{array}$ & $\begin{array}{c}\text { Liczba podmiotów } \\
\text { osób fizycznych/1000 } \\
\text { mieszkańców }\end{array}$ \\
\hline Aleksandrów Łódzki & 21354 & 1918 & 89,8 \\
\hline Ozorków & 19879 & 1140 & 57,3 \\
\hline Konstantynów Łódzki & 17807 & 1431 & 80,4 \\
\hline
\end{tabular}

\footnotetext{
${ }^{1}$ Dane za: GUS 2017 r.
} 


\begin{tabular}{|l|r|r|r|}
\hline Głowno & 14590 & 1076 & 73,8 \\
\hline Koluszki & 13302 & 1070 & 80,4 \\
\hline Brzeziny & 12542 & 1024 & 81,6 \\
\hline Tuszyn & 7261 & 705 & 97,1 \\
\hline Stryków & 3492 & 250 & 71,6 \\
\hline Rzgów & 3396 & 419 & 123,4 \\
\hline
\end{tabular}

Źródło: opracowanie własne na podstawie danych GUS

Przedsiębiorcy i przedsiębiorczość w opinii mieszkańców

Konstantynowa Łódzkiego - wyniki badań

Wyniki przeprowadzonych badań wskazują, że termin „przedsiębiorczość” jest przez respondentów różnie interpretowany, ale generalnie budzi on pozytywne skojarzenia. Wprawdzie większość z badanych (62\%) przedsiębiorczość pojmuje tradycyjnie, czyli utożsamia ją z zakładaniem prywatnej działalności gospodarczej, ale dla co trzeciego z nich (32\%) przedsiębiorczość to także cecha, umiejętność wykorzystania czynników głównie o charakterze społecznym, politycznym, prawnym, sprzyjających społeczno-gospodarczemu rozwojowi miasta. $\mathrm{W}$ ich opinii jest ona nie tylko atrybutem prywatnej inicjatywy, ale także istotnym czynnikiem warunkującym rozwój miasta. Stanowisko to potwierdza także zadeklarowany przez respondentów stosunek do stwierdzenia, że przedsiębiorczość jest istotną determinantą rozwoju społeczno-gospodarczego miasta. Aż 46\% badanych w pełni zgodziło się z tym stwierdzeniem, a tylko $6 \%$ była przeciwnego zdania.

Podobnie pozytywne skojarzenia wśród respondentów budzi określenie „przedsiębiorca”. Na pytanie, kim jest przedsiębiorca, najczęściej padała bowiem odpowiedź, że przedsiębiorca to człowiek, który jest źródłem dobrobytu miasta (48\% badanych) oraz że jest to człowiek budzący ogólny szacunek i podziw (32\%). Skojarzeń negatywnych z tym określeniem było znacznie mniej. Tylko 6\% respondentów przyznało, że ich zdaniem to człowiek, który bogaci się kosztem innych, a kolejne $2 \%$, że to człowiek nieuczciwy, gdyż dla własnych korzyści unika płacenia podatków.

Szczegółowa analiza cech, jakie zdaniem badanych wyróżniają lokalnych przedsiębiorców, również wskazuje na ich ogólnie pozytywny odbiór przez społeczeństwo. Znacznie częściej bowiem respondenci przypisywali przedsiębiorcom cechy pozytywne, takie jak zaradność, inteligencja, komunikatywność, niż negatywne (arogancja, egoizm) (rycina 2).

Warto jednak podkreślić, że stosunek społeczności lokalnej do przedsiębiorców zmienia się wraz z wiekiem. W przeprowadzonych badaniach wyraźnie widać, że dużo lepszą opinią przedsiębiorcy cieszą się wśród młodszych roczników, tj. do 30-35 roku życia, niż wśród starszych, tj. po 50-60 roku życia. Można zatem stwierdzić, że na naszych oczach dokonuje się pewna zmiana pokoleniowa w postrzeganiu przedsiębiorców, czyli polskie społeczeństwo powoli wyzwala się z negatywnego obrazu ludzi biznesu. Przekonanie o społecznej pożyteczności przedsiębiorców rośnie także wraz z wykształceniem i zamożnością. Zaobserwowana tu tendencja pojawiła się już w innych tego typu badaniach, co pozwala sądzić, że ma ona raczej trwały charakter (patrz: Braziewicz-Kumor, 2016).

Postawa społeczności względem danej grupy społecznej pozostaje pod dużym wpływem źródła, z którego społeczność czerpie o niej informacje. W przypadku respondentów w największym stopniu obraz lokalnego przedsiębiorcy kształtowany jest przez 
Rycina 2. Cechy osobowe przedsiębiorców najczęściej wymieniane przez respondentów

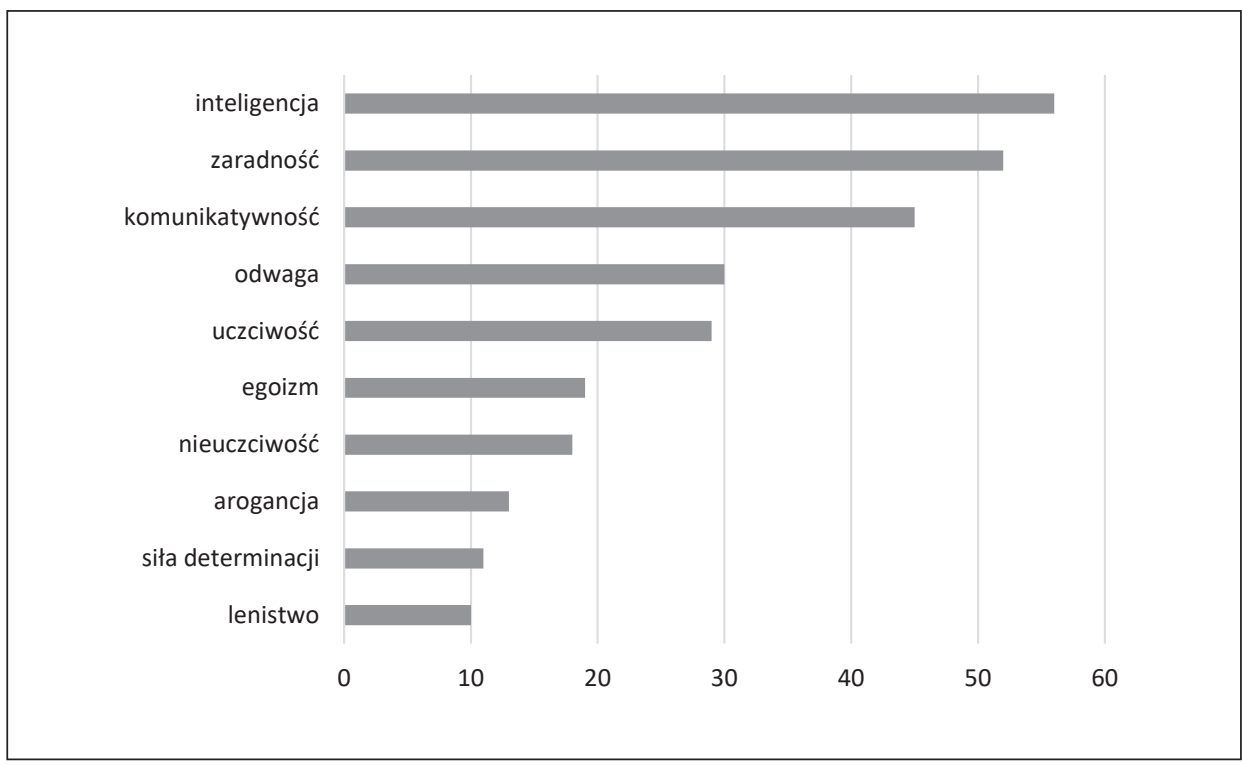

Źródło: opracowanie własne na podstawie badań ankietowych

osobiste doświadczenia nabyte w toku pracy u lokalnego przedsiębiorcy (64\%). Znacznie rzadziej natomiast jest on wypadkową tego, co respondenci usłyszą lub przeczytają o przedsiębiorcach w lokalnych mediach (36\%). Taki rozkład odpowiedzi pozwala zatem sądzić, że respondenci, opisując przedsiębiorców, nie kierują się stereotypem będącym, jak stwierdzili Pocock i Hudson (1978), skrajnie uproszczonym obrazem rzeczywistości, lecz odwołują się do własnych doświadczeń, przeżyć i emocji, z których następnie budują indywidualny obraz rzeczywistości.

W kontekście tego pozytywnego odbioru przedsiębiorców i przedsiębiorczości przez społeczność lokalną interesująca wydaje się ich opinia o możliwościach, jakie stwarza miasto dla rozwoju biznesu. Jest ona interesująca, ponieważ na tle innych małych miast województwa łódzkiego Konstantynów Łódzki wypada przeciętnie pod względem liczby podmiotów osób fizycznych. Zdaniem większości respondentów, Konstantynów Łódzki jest miastem, które sprzyja przedsiębiorcom. Blisko $60 \%$ badanych oceniło miasto dobrze i bardzo dobrze pod kątem możliwości założenia i rozwoju własnego biznesu. Wysoko została także oceniona praca władz lokalnych na rzecz pobudzenia lokalnej przedsiębiorczości. Warto jednak zauważyć, że decyzja o założeniu własnej firmy pozostaje nie tylko pod wpływem warunków lokalnych, ale także tych oferowanych przez państwo oraz jest ona wypadkową umiejętności i kreatywności działania przedsiębiorczego pojedynczych ludzi. Respondenci zdają się dostrzegać wagę tych czynników, ponieważ spośród wielu wymienionych przez nich barier najwięcej wskazań otrzymały te, których źródłem są uwarunkowania osobowościowe oraz makroekonomiczne (rycina 3). Ich zdaniem największą przeszkodą w prowadzeniu własnego biznesu jest bowiem po pierwsze, brak wiedzy i doświadczenia w prowadzeniu tego typu działalności, a po drugie - nadmierna biurokracja do spółki z nieprzejrzystym i niestabilnym systemem przepisów prawnych. Dlatego też, w ich opinii, uproszczenie istniejącego systemu podatkowego, zwiększenie liczby 
Rycina 3. Bariery utrudniające zakładanie prywatnych firm w Konstantynowie Łódzkim w opinii respondentów

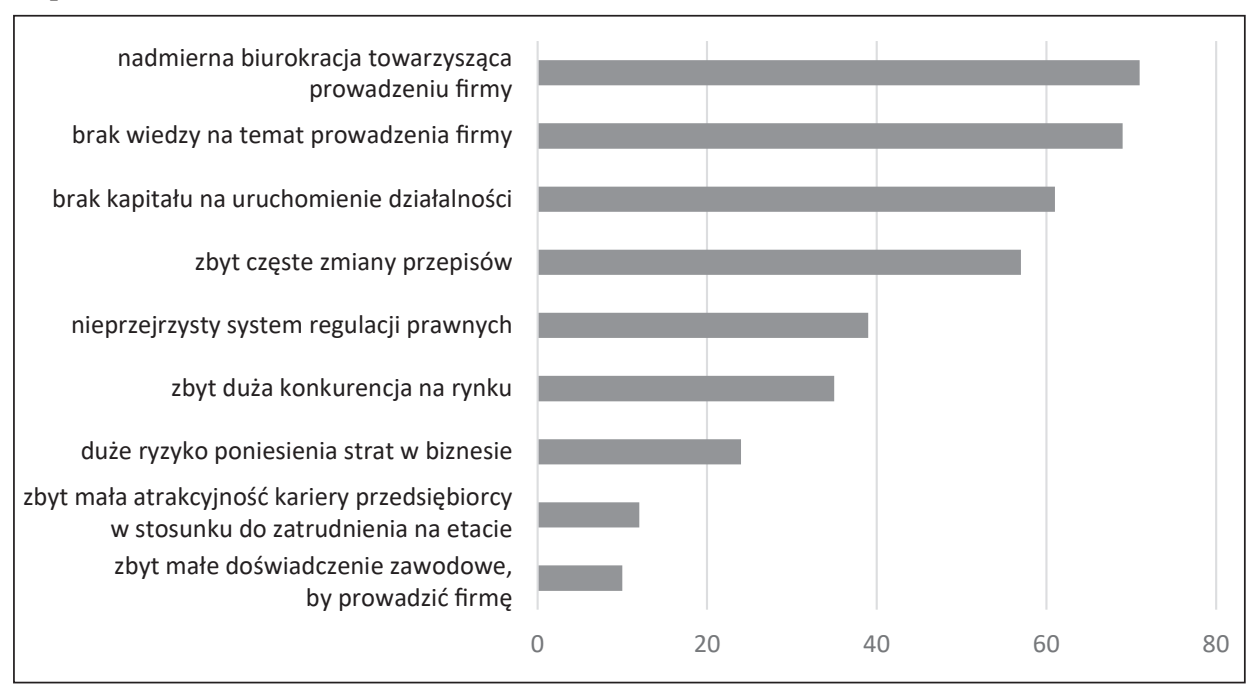

Źródło: opracowanie własne na podstawie badań ankietowych.

szkoleń i warsztatów, szczególnie dla początkujących przedsiębiorców, oraz zmniejszenie liczby super- i hipermarketów znacznie ułatwiłoby wejście w rolę przedsiębiorcy i rozwój firm już istniejących.

\section{Wnioski}

W polskiej literaturze naukowej przedsiębiorczość jest rozumiana w różnoraki sposób. Najczęściej jednak definiuje się ją dwojako: jako zbiór cech osoby przedsiębiorczej (płaszczyzna socjologiczna, psychologiczna) oraz jako proces, czyli sposób podejmowania działań przez osoby przedsiębiorcze (płaszczyzna ekonomiczna, organizacyjna). Przybliżając problem, można powiedzieć, że przedsiębiorczość w definicjach to z jednej strony cecha charakteru przejawiająca się w określonych zachowaniach człowieka lub grup ludzi, zaś z drugiej strony, szczególna forma aktywności jednostki lub grup wyrażająca się w działaniu (Grzegorzewska-Mischka, 2010). Niezależnie jednak od sposobu jej ujmowania współcześnie przypisuje się jej wiodącą rolę w rozwoju społeczno-gospodarczym. To sprawia, że władze lokalne poszukują wciąż nowych, kreatywnych możliwości jej pobudzenia. Współczesne badania coraz częściej jednak dowodzą, że równie ważne jak działanie jest też odpowiednie nastawienie społeczności lokalnej do przedsiębiorców i przedsiębiorczości. Dlatego też coraz częściej podejmowane są badania nad wizerunkiem przedsiębiorcy i przedsiębiorczości w społeczeństwie. Wizerunek, podobnie jak przedsiębiorczość, uchodzi bowiem współcześnie za bardzo ważny element życia społeczno-gospodarczego, którego jedną z wiodących funkcji jest możliwość wywierania pozytywnego lub negatywnego wpływu na zachowania społeczne. Innymi słowy - daje on możliwość kształtowania pożądanych zachowań społecznych, czyli może też odegrać kluczową rolę w rozwoju przedsiębiorczości. 
Nawet pobieżny przegląd prowadzonych w ostatnich latach badań nad wizerunkiem przedsiębiorcy pozwala zauważyć, że w ciągu ostatnich 10 lat nastąpiła istotna zmiana w jego postrzeganiu. O ile jeszcze w 2003 r. $^{2}$ Polacy przypisywali przedsiębiorcom wiele negatywnych cech, m.in.: wykorzystywanie znajomości i powiązań w różnych instytucjach, skłonność do wywyższania się, dbania tylko o własny interes i nieuczciwość, o tyle już w 2015 r. ich wizerunek w oczach Polaków wyraźnie się ocieplił i w miejsce negatywnych cech pojawiły się także pozytywne opinie, takie jak: przedsiębiorcy tworzą miejsca pracy, budują siłę i jakość polskiej gospodarki, to dzięki nim polski rząd ma pieniądze na utrzymanie służby zdrowia, szkól, policji, wojska itp. ${ }^{3}$

Zmianę nastawienia społeczeństwa polskiego do przedsiębiorców pokazały także badania przeprowadzone $\mathrm{w}$ niniejszym artykule. Opinie wyrażone przez respondentów wyraźnie sugerują, że Konstantynów Łódzki cechuje się klimatem sprzyjającym przedsiębiorcom i rozwojowi przedsiębiorczości. Ogólny ich wizerunek jest bowiem pozytywny i, jak się wydaje, nie ma już nic wspólnego z dawnymi pejoratywnymi określeniami „badylarz” czy „prywaciarz”. Główną barierą dla rozwoju prywatnych firm wciąż jednak pozostają uwarunkowania makroekonomiczne, na które sami zainteresowani nie mają wpływu, są one bowiem od nich niezależne. Wyniki tych badań pozwalają zatem na stwierdzenie, że przynajmniej w Konstantynowie Łódzkim pierwsza bariera wynikająca z mentalności i sposobu postrzegania przedsiębiorcy została na trwale usunięta. Pozostały jednak jeszcze inne, które wbrew pozorom trudniej będzie usunąć, gdyż często są one wypadkową prywatnych interesów ludzi, których wpływ na rozwój miasta jest największy.

Literatura

References

Bartnicka, M. (1986). Percepcja przestrzeni miejskiej Warszawy na przykładzie dzielnicy Ochota. Przegląd Geograficzny, 58(1-2).

Bartnicka, M. (1989). Wyobrażenia przestrzeni miejskiej Warszawy - studium geografii percepcji. Dokumentacja Geograficzna, 2.

Braziewicz-Kumor, O. (2016). Wizerunek polskiego przedsiębiorcy. Studia i Materiały. Miscellanea Oeconomicae, 20(2), 473-481

Budner, W., Matykowski, R. (1992). Regionalizm i świadomość regionalna mieszkańców Wielkopolski. Zeszyty Naukowe. Akademia Ekonomiczna w Poznaniu, I(204).

Bujanowska, A. (2009). Uwarunkowania postaw studentów pedagogiki wobec osób niepełnosprawnych. Lublin: Wydawnictwo Uniwersytetu Marii Curie-Skłodowskiej.

Cierniak-Szóstak, E. (2006). Mentalność ekonomiczna jako czynnik prorozwojowy. Nierówności Społeczne a Wzrost Gospodarczy, 8, 197-207.

Cierniak-Szóstak, E. (2008). Wizerunek polskiego przedsiębiorcy jako element społecznej legitymizacji/ delegitymizacji nowego ładu. Nierówności Społeczne a Wzrost Gospodarczy w Kontekście Spójności Społeczno-Ekonomicznej. 13, 397-408.

Landes, D. S. (1951). French Business and the Businessman: A Social and Cultural Analysis, W: E.M. Earle (red.), Modern France. Princeton: Princeton University Press.

Sawyer, J.E. (1952). The Entrepreneur and the Social Order: France and the United States, W: W. Miller (red.), Men in Business: Essays in the History of Entrepreneurship. Cambridge: Harvard University Press.

\footnotetext{
${ }^{2}$ Badania CBOS (za: Braziewicz-Kumor, 2016).

${ }^{3}$ Rzetelna Firma 2015. Raport „Przedsiębiorcy obraz pełen sprzeczności” (za: Braziewicz-Kumor, 2016).
} 
Domański, B. (1997). Geografia przedsiębiorstw - niedoceniany nurt badań w polskiej geografii ekonomicznej. W: B. Domański, A. Jackowski (red.), Geografia. Człowiek. Gospodarka. Profesorowi Bronisławowi Kortusowi w 70. rocznicę urodzin. Kraków: Instytut Geografii UJ, 55-65.

Fierla, I., Kuciński, K. (red.). (2001). Lokalizacja przedsiębiorstw a konkurencyjność. Warszawa, Wydawnictwo Szkoły Głównej Handlowej w Warszawie.

Glinka, B. (2008). Kulturowe uwarunkowania przedsiębiorczości w Polsce. Warszawa: Polskie Wydawnictwo Ekonomiczne.

Gwosdz, K. (2001). Postrzeganie regionu tradycyjnego przemysłu w okresie transformacji: przypadek Górnego Śląska. Czasopismo Geograficzne, 72(3-4), 283-299.

Hryniewicz, J.T. (1996). Przesłanki rozwoju gospodarczego gmin. Ekonomista, 6, 797-811.

Jasicki, K. (2004). Społeczna odpowiedzialność biznesu w oczach Polaków. W: L. Kolarska-Bobińska (red.), Świadomość ekonomiczna społeczeństwa i wizerunek biznesu. Warszawa: Instytut Spraw Publicznych.

Jałowiecki, B. (1996). Świadomość regionalna młodzieży licealnej. Studia Regionalne i Lokalne, 17(50).

Kaczmarek, J., Szafrańska, E. (2007). Percepcja przestrzeni - pomiędzy prawdą a autentycznością, W: M. Madurowicz (red.), Percepcja współczesnej przestrzeni miejskiej. Warszawa: Wydawnictwo Uniwersytetu Warszawskiego, 47-62.

Kamińska, W. (1997). Prywatna przedsiębiorczość na obszarze wschodniego pogranicza w Polsce. W: M. Jakubowski (red.), Strategiczne znaczenie polskiej granicy wschodniej i polskiego pogranicza wschodniego, Geopolitical Studies, 3, 113-155.

Kamińska, W. (2006). Pozarolnicza indywidualna działalność gospodarcza w Polsce w latach 1988-2003, Warszawa: IGiPZ PAN.

Kola-Bezka, M. (2012). Postrzeganie przedsiębiorczości w czasach kryzysu - wyniki badania ankietowego mieszkańców wsi i miast województwa kujawsko-pomorskiego i warmińsko-mazurskiego. Nierówności Społeczne a Wzrost Gospodarczy, 25, 287-295.

Kulawiak, A. (2011). Zmiana lokalnych społecznych uwarunkowań rozwoju gospodarczego Łodzi w latach 2002-2010 w świetle badań łódzkich przedsiębiorców. Rozprawy Naukowe Instytutu Geografii, 20, 171-185.

Kulawiak, A., (2013). Społeczne uwarunkowania rozwoju sektora usług w małych miastach. Przykład Uniejowa. Folia Geographica Socio-Oeconomica, 15, 115-126.

Suliborski, A., Kulawiak A. (2006). Przedsiębiorca - jako uczestnik i twórca procesów transformacji. Przykład Łodzi, W: A. Jewtuchowicz, A. Suliborski (red.), Przestrzenne zróżnicowanie procesów transformacji społeczno-gospodarczej. Łódź: Wydawnictwo Uniwersytetu Łódzkiego, 159-183.

Kulawiak, A. (2012). Zmiana społecznych, lokalnych uwarunkowań rozwoju gospodarczego w latach 2002-2010 w świetle badań łódzkich przedsiębiorców. Prace Naukowe Instytutu Geografii i Rozwoju Regionalnego Uniwersytetu Wrocławskiego, 2, 81-96.

Libura, H. (1988). Badania wyobrażeń geograficznych na przykładzie mieszkańców Sanoka. Dokumentacja Geograficzna, 1 .

Libura, H. (1990). Percepcja przestrzeni miejskiej. Warszawa: Wydawnictwo Europejskiego Instytutu Rozwoju Regionalnego i Lokalnego, Uniwersytet Warszawski.

Madurowicz, M., (red.). (2007). Percepcja współczesnej przestrzeni miejskiej. Warszawa: Wydawnictwo Uniwersytetu Warszawskiego.

Majewska, K. (2003). Wizerunek polskiego biznesu w prasie, W: W. Kozek (red.), Instytucjonalizacja stosunków pracy w Polsce, Warszawa: Wydawnictwo Naukowe Scholar.

Mordwa, S. (1993). Wyobrażenia przestrzeni miejskiej Łodzi. Łódź: Wydawnictwo Uniwersytetu Łódzkiego.

Mordwa, S. (2003). Wyobrażenia miast Polski środkowej. Łódź: Wydawnictwo Uniwersytetu Łódzkiego.

Pałka, E. (2010a). Pozarolnicza działalność gospodarcza w indywidualnych gospodarstwach rolnych województwa świętokrzyskiego. Kielce: Wydawnictwo Uniwersytetu Jana Kochanowskiego.

Pałka, E. (2010b). Kierunki rozwoju pozarolniczej działalności na obszarach wiejskich w Polsce. Infrastruktura i Ekologia Terenów Wiejskich, 1, 163-174. 
Roguska, B. (2004). Właściciel, pracodawca, obywatel - rekonstrukcja wizerunku prywatnego przedsiębiorcy, W: L. Kolarska-Bobińska (red.), Świadomość ekonomiczna społeczeństwa i wizerunek biznesu. Warszawa: Instytut Spraw Publicznych.

Rykiel, Z. (1985). Badanie świadomości regionalnej - przykład regionu katowickiego. Przegląd Geograficzny, Dokumentacja Geograficzna, 3-4, 37-58.

Tkaczyk, J., Rachwalska, J. (1997). Wszystko jest obrazem. Kształtowanie wizerunku przedsiębiorstwa. Marketing i Rynek, 5(97), 5-10

Rembowska, K. (2000). Tożsamość lokalna i regionalna. Region łódzki. Acta Universitatis Lodziensis. Folia Geographica Socio-Oeconomica, 3, 3-9.

Stryjakiewicz, T. (2009). Nowe spojrzenie na czynniki lokalizacji działalności gospodarczej. W: I. Jażewicz (red.), Wspótczesne problemy przemian strukturalnych przestrzeni geograficznej. Słupsk: Wydawnictwo Naukowe Akademii Pomorskiej, 94-102

Smętkiewicz, K. (2014). Świadomość społeczna wykorzystania wód geotermalnych w województwie łódzkim i landzie Styria w kontekście zrównoważonego rozwoju regionów. Łódź: Wydawnictwo Uniwersytetu Łódzkiego.

Szkurłat, E. (2004). Więzi terytorialne młodzieży z miastem. Uwarunkowania, przemiany. Łódź: Wydawnictwo Uniwersytetu Łódzkiego.

Szkurłat, E. (2006). Miasto w świadomości młodzieży. Stereotypowy obraz Łodzi. Kronika Miasta Łodzi, $1,107-120$.

Szkurłat, E. (2007). Psychologiczne i kulturowe uwarunkowania percepcji środowiska. W: M. Madurowicz (red.), Percepcja wspótczesnej przestrzeni miejskiej. Łódź: Wydawnictwo Uniwersytetu Łódzkiego, 63-72.

Szymańska, A., Płaziak, M. (2010). Klasyczne czynniki w procesie lokalizacji przedsiębiorstwa na wybranych przykładach. Przedsiębiorczość - Edukacja, 10, 71-84.

Śleszyński, P. (2002). Struktura i koncentracja przestrzenna siedzib ważniejszych przedsiębiorstw w Warszawie w 1999 r. Prace Komisji Geografii Przemystu PTG, 4, 89-113.

Śleszyński, P. (2003). Rozkład przestrzenny działalności gospodarczej w aglomeracji warszawskiej. Przegląd Geograficzny, 75(3), 403-432.

Tobiasz-Lis, P. (2013). Zmiany wyobrażeń mieszkańców Łodzi o przestrzeni miasta. Łódź: Wydawnictwo Uniwersytetu Łódzkiego.

Wolińska, J. (2015). Percepcja społeczna i stereotyp niepełnosprawności. Annales Universitatis Mariae Curie-Skłodowska, 28, 45-66.

Anita Kulawiak, dr nauk o Ziemi, adiunkt w Katedrze Geografii Regionalnej i Społecznej na Wydziale Nauk Geograficznych Uniwersytetu Łódzkiego. Zainteresowania badawcze autorki skupiają się wokół zagadnień związanych z szeroko rozumianą przedsiębiorczością w małych miastach i na obszarach wiejskich, transformacją polskiej gospodarki oraz wykorzystaniem funduszy UE w różnych skalach przestrzennych. Jest autorką i współautorką ponad 30 artykułów naukowych.

Anita Kulawiak, $\mathrm{PhD}$ in Geography, assistant professor in the Department of Regional and Social Geography of the University of Lodz. The author's research interests focus on the issues of entrepreneurship in small towns and rural areas, the transformation of the Polish economy and the use of EU funds in a variety of spatial scales. She is the author or co-author of about 30 publications.

ORCID: 0000-0002-7458-0330

\author{
Adres/Address: \\ Uniwersytet Łódzki \\ Wydział Nauk Geograficznych \\ Katedra Geografii Regionalnej i Społecznej \\ ul. Kopcińskiego 31 \\ 90-142 Łódź, Polska \\ e-mail: anita.kulawiak@geo.uni.lodz.pl
}


Karolina Smętkiewicz, dr, adiunkt w Instytucie Geografii Uniwersytetu Pedagogicznego im. Komisji Edukacji Narodowej w Krakowie (od 2017 r.). W 2014 r. uzyskała na Uniwersytecie Łódzkim stopień naukowy doktora nauk o Ziemi w zakresie geografii społeczno-ekonomicznej. Zainteresowania naukowo-badawcze autorki związane są m.in. z wykorzystaniem lokalnych zasobów (w szczególności wód geotermalnych) do rozwoju gospodarczego miejscowości i regionów, aktywizacji społecznej i wzrostu przedsiębiorczości. Autorka zajmuje się głównie problematyką przemian społeczno-gospodarczych i funkcjonalno-przestrzennych miejscowości turystycznych i uzdrowiskowych w Polsce i Austrii, a także zagadnieniem działań edukacyjnych mających na celu budowanie świadomości ekologicznej i wspomaganie zrównoważonego rozwoju miejscowości. Dzięki prowadzonym badaniom naukowym podczas pobytów stypendialnych na uczelniach w Niemczech i Austrii zdobywała wiedzę i doświadczenie m.in. w zakresie możliwości rozwoju regionalnego w oparciu o lokalne zasoby przyrody i uwarunkowania społeczno-gospodarcze, szczególnie w kontekście rozwoju turystycznego. W latach 2013-2017 jako pracownik Działu Promocji Urzędu Miasta w Uniejowie zajmowała się m.in. działaniami związanymi z promowaniem lokalnych zasobów przyrody i dziedzictwa historyczno-kulturowego, wspieraniem lokalnej przedsiębiorczości oraz edukacją ekologiczną, wdrażając w ten sposób wyniki pracy naukowej w działania praktyczne.

Karolina Smętkiewicz, $\mathrm{PhD}$, assistant professor in the Institute of Geography, Pedagogical University of Cracow (since 2017). In 2014, she obtained the PhD degree in Earth Sciences in the field of socio-economic geography at the University of Lodz. The author's research interests are related to using local resources (in particular geothermal waters) for the economic development of towns and regions, social activity and growth of entrepreneurship. The author deals mainly with the problems of socio-economic and functional-spatial changes of tourist and health resorts in Poland and Austria, as well as the issue of educational activities aimed at building ecological awareness and supporting sustainable development of towns. Thanks to scientific research during scholarship stays at universities in Germany and Austria, she has gained knowledge and experience, among others, in the field of regional development opportunities based on local natural resources and socio-economic determinants, especially in the context of tourism development. In the years 2013-2017, as an employee of the Promotion Department of the Uniejów Municipality she dealt with, among others, activities related to the promotion of local natural resources and historical and cultural heritage and supporting of local entrepreneurship, as well as ecological education, thus implementing the results of scientific work in practical activities.

ORCID: 0000-0002-3277-1876

\section{Adres/Address:}

Uniwersytet Pedagogiczny im. Komisji Edukacji Narodowej w Krakowie

Instytut Geografii

Zakład Przedsiębiorczości i Gospodarki Przestrzennej

ul. Podchorążych 2

30-084 Kraków, Polska

e-mail: karolina.smetkiewicz@up.krakow.pl

Artykuł napisany w ramach badań statutowych Katedry Geografii Regionalnej i Społecznej Wydziału Nauk Geograficznych UŁ (A. Kulawiak) oraz badań statutowych Zakładu Przedsiębiorczości i Gospodarki Przestrzennej Wydziału Geograficzno-Biologicznego UP w Krakowie (K. Smętkiewicz). 